\title{
New species of Ophiostomatales from Scolytinae and Platypodinae beetles in the Cape \\ Floristic Region, including the discovery of the sexual state of Raffaelea
}

\section{Tendai Musvuugwa}

Department of Botany and Zoology, Stellenbosch University, Private Bag X1, Stellenbosch, 7600, South Africa

\section{Z. Wilhelm de Beer}

Department of Microbiology and Plant Pathology, Forestry and Agricultural Biotechnology Institute (FABI),

University of Pretoria, Pretoria 0002, South Africa

\section{Tuan A. Duong}

Department of Genetics, Forestry and Agricultural Biotechnology Institute (FABI), University of Pretoria, Pretoria 0002, South Africa

\section{Léanne L. Dreyer}

Department of Botany and Zoology, Stellenbosch University, Private Bag X1, Stellenbosch, 7600, South Africa and DSTNRF Centre of Excellence in Tree Health Biotechnology (CTHB), Forestry and Agricultural Biotechnology Institute (FABI), University of Pretoria, Private Bag X20, Hatfield, Pretoria, 0028, South Africa

\section{Kenneth C. Oberlander}

Institute of Botany, Academy of Sciences, Průhonice, CZ - 252 43, Czech Republic and Department of Conservation Ecology and Entomology, Stellenbosch University, Private Bag X1, Stellenbosch, 7600, South Africa

\section{Francois Roets (corresponding author)}

Department of Conservation Ecology and Entomology, Stellenbosch University, Private Bag X1, Stellenbosch, 7600, South Africa and DST/NRF Centre of Excellence in Tree Health Biotechnology (CTHB), Forestry and Agricultural Biotechnology Institute (FABI), University of Pretoria, Private Bag X20, Hatfield, Pretoria, 0028,

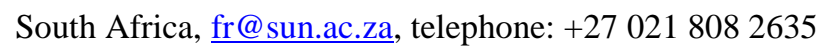

Abstract Olea capensis and Rapanea melanophloeos are important canopy trees in South African Afromontane forests. Dying or recently dead individuals of these trees are often infested by Scolytinae and Platypodinae (Curculionidae) beetles. Fungi were isolated from 
the surfaces of beetles emerging from wood samples and their galleries. Based on micromorphological and phylogenetic analyses, four fungal species in the Ophiostomatales were isolated. These were Sporothrix pallida and three taxa here newly described as $S$.

aemulophila sp. nov., Raffaelea vaginata sp. nov. and Raffaelea rapaneae sp. nov. This study represents the first collection of $S$. pallida, a species known from many environmental samples from across the world, from Scolytinae beetles. Sporothrix aemulophila sp. nov. is an associate of the ambrosia beetle Xyleborinus aemulus. Raffaelea rapaneae sp. nov. and $R$. vaginata sp. nov. were associated with a Lanurgus sp. and Platypodinae beetle, respectively, and represent the first Raffaelea spp. reported from the Cape Floristic Region. Of significance is that $R$. vaginata produced a sexual state analogous with those of Ophiostoma seticolle and O. deltoideosporum that also grouped in our analyses in Raffaelea s. str., to date considered an asexual genus. The morphology of the ossiform ascospores and anamorphs of the three species corresponded and the generic circumscription of Raffaelea was thus emended to accommodate sexual states. The two known species were provided with new combinations, namely Raffaelea seticolle (R.W. Davidson) Z.W. de Beer \& T.A. Duong comb. nov. and Raffaelea deltoideospora (Olchow. \& J. Reid) Z.W. de Beer \& T.A. Duong comb. nov.

Keywords Olea, Ophiostoma, Platypodinae, Raffaelea, Rapanea, Scolytinae

\section{Introduction}

Olea capensis L. ssp. macrocarpa (C. H. Wright) I. Verd. (Oleaceae) and Rapanea melanophloeos Mez. (Myrsinaceae) are important canopy trees in the evergreen Afromontane forests of Africa. In southern Africa both species are distributed from Zambia to Cape Town, South Africa (Van Wyk and Van Wyk 1997). Although both trees are renowned for their 
attractive wood utilised for making furniture, not much is known regarding their associated organisms. The recent description of a serious stem canker disease of $R$. melanophloeos from the Cape Floristic Region (CFR) in South Africa, caused by the fungus Immersiporthe knoxdaviesiana S.F. Chen, MJ. Wingf. \& Jol. Roux (Chen et al. 2013), highlighted the importance of understanding such relationships and led to the research reported here.

Apart from pathogens, wood boring insects, such as bark and ambrosia beetles (Coleoptera: Curculionidae, Scolytinae and Platypodinae), may also represent a significant, but grossly understudied threat to native trees in these forests. These beetles form part of a diverse group that bore into a broad spectrum of trees, shrubs and other woody plants (Atkinson and Equihua 1986; Atkinson and Peck 1994). They are rated as some of the globally most important forest pests (Paine et al. 1997; Harrington 2005; Avtzis et al. 2012), including more than 6000 species in 225 genera (Knižek and Beaver 2004; Avtzis et al. 2012; Six 2012). They are usually found infesting conifers and hardwood trees (Avtzis et al. 2012). The Platypodinae includes about 1500 described species of ambrosia beetles (Wood and Bright 1992; Beaver and Liu 2013), most of which are found in tropical and sub-tropical regions (Schedl 1972). There they are of economic importance, often penetrating felled timber along with their associated fungi, causing wood staining (Browne 1968). The ecology of very few Scolytinae and Platypodinae beetle species has been well-studied and these studies have mainly focussed on Northern Hemisphere systems (Batra 1967; Farrell et al. 2001). In Africa, their diversity and effects on tree hosts, especially on native trees, is virtually unknown (Jordal et al. 2001; Beaver 2005).

For part of their life cycles, scolytine bark beetles reside in galleries under bark, whereas the galleries of scolytine- and platypodinae ambrosia beetles are found within the wood of their hosts. As they penetrate these tissues they can introduce a diverse array of fungi that colonises the wood from within the gallery system (Batra 1966; Whitney 1982). 
Ambrosia beetles depend on their fungal symbionts for nutrition (Batra 1966), while bark beetles mainly feed on the phloem of trees, with nutritional supplementation of their diets by some of their fungal associates (Harrington 2005; Six 2003). In some cases the relationship between these two organism groups is therefore mutualistic. The fungi provide nutrients for use during reproduction and hormone synthesis, to help overcome tree defence mechanisms and to protect beetles against antagonistic fungi (Berryman 1972; Harrington 1993;

Wingfield et al. 1995; Paine et al. 1997; Klepzig et al. 2001; Klepzig and Six 2004). In turn, the fungi are transported by the beetles from one host tree to the next under favourable conditions (Klepzig et al. 2001; Klepzig and Six 2004). In many cases the interaction is so strong that specialised spore-carrying structures (mycangia) have evolved in the beetles, but spores may also be transported on the exoskeletons and within the alimentary canal of some taxa (Batra 1967; Beaver 1989; Paine et al. 1997; Six 2003; Klepzig and Six 2004).

Fungi from the Ophiostomatales are some of the most common fungal associates of bark and ambrosia beetles (Barras and Perry 1972; Bridges and Moser 1983; Jacobs and Wingfield 2001; Klepzig et al. 2001; Six 2003; Klepzig and Six 2004; Harrington 2005; Alamouti et al. 2009). The order includes genera such as Ceratocystiopsis Upadhyay \& Kendrick, Graphilbum H.P. Upadhyay \& W.B. Kendr., Leptographium Lagerb. \& Melin, Ophiostoma Syd. and Raffaelea Arx \& Hennebert (Upadhyay 1981; Zipfel et al 2006; De Beer and Wingfield 2013), some of which contain important tree pathogens (Heybroek 1993; Brasier and Buck 2001; Zhou et al. 2001). Well-documented examples are those of Ophiostoma ulmi (Buisman) Nannf. and O. novo-ulmi Brasier that are transported by the European elm bark beetle (Scolytus multistriatus Marsham) (Webber 1990) and the American elm bark beetle (Hylurgopinus rufipes Eichhoff). These two pathogens cause Dutch elm disease in Europe and the United States of America (Brasier 2000; Pipe et al. 2000). Raffaelea lauricola T.C. Harr., Fraedrich \& Aghayeva, transported by the ambrosia beetle 
Xyleborus glabratus Eichhoff (Harrington et al. 2008), is responsible for Laurel wilt disease in the southeastern United States of America (Harrington et al. 2008; Ploetz et al. 2013), and in Japan, the ambrosia beetle Platypus quercivorus Murayama and its associate fungus Raffaelea quercivora Kubono et Shin. Ito were responsible for the catastrophic mass mortality and die-back of Japanese oak trees (Kubono and Ito 2002).

There are very few reports of members of the Ophiostomatales associated with subcortical beetles on native trees in southern Africa. Inadequate information on these insects and their fungal symbionts hinders our understanding of the death of some of these native tree species. The recent discovery of some ambrosia beetles and their associated fungi causing the decline of the native Euphorbia ingens E. Meyer: Boissier in South Africa (Roux et al. 2009; Van der Linde et al. 2012) highlighted the need for more research on these beetles and their effects on other native tree taxa in South Africa. During recent surveys of native trees in South Africa, many individuals of $R$. melanophloeos and $O$. capensis ssp. macrocarpa were found to be infested by bark and ambrosia beetles. These beetles were most often associated with dying or recently dead trees. Given the gap in our knowledge, and the importance of beetle-associated Ophiostomatales to tree health, this study aimed to document the fungi associated with the bark and ambrosia beetles from these two tree taxa, focussing specifically on Afromontane forests of the CFR of South Africa.

\section{Materials and methods}

Beetle sampling

Sampling was conducted in forests adjacent to the Harold Porter National Botanical Garden

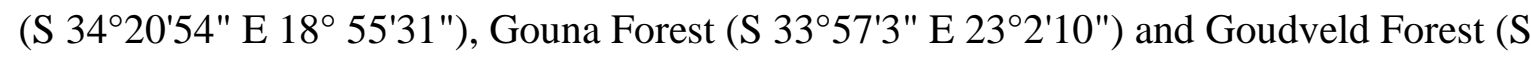
33 $54^{\circ} 44^{\prime \prime}$ E $\left.23^{\circ} 0^{\prime} 10^{\prime \prime}\right)$ in the Western Cape Province of South Africa between 2010 and 2012. 
Bark and wood samples were collected from dyng or recently dead $R$. melanophloeos and $O$. capensis ssp. macrocarpa trees that showed signs of subcortical beetle activity. The collected plant material was transferred to the laboratory and placed in insect emergence cages constructed from sealed cardboard boxes $($ ca. $49 \times 49 \times 32.6 \mathrm{~cm}$ ) fitted with two transparent plastic bottles $(5.7 \mathrm{~cm}$ diameter) on one side. Light penetrating through the plastic containers attracted emerging beetles, causing them to accumulate in the bottles, from where they could easily be collected. Emergence cages were maintained at room temperature and inspected every 2-3 d for a period of $50 \mathrm{~d}$. Individual beetles were aseptically placed in sterile vials, grouped into morpho-species, their numbers recorded and stored at $4{ }^{\circ} \mathrm{C}$ until further use (but not longer than 5 d). Reference collections of all beetle taxa collected in this study were stored in $70 \%$ ethanol. Reference material was sent for identification by expert taxonomists and is maintained in the Insect Collection of Stellenbosch University (USEC), Stellenbosch, South Africa.

Fungal isolation from beetles and beetle galleries

Wood from emergence cages was examined for the presence of ascocarps of members of the Ophiostomatales. When present, ascospores were removed from the apices of ascomatal necks with a dissecting needle and transferred to 2\% Malt Extract Agar (MEA; Biolab, Midrand, South Africa) amended with 0.05 g/L cycloheximide (Harrington 1981). Depending on availability, 3 to 50 beetle individuals per beetle morpho-species were placed in eppendorf

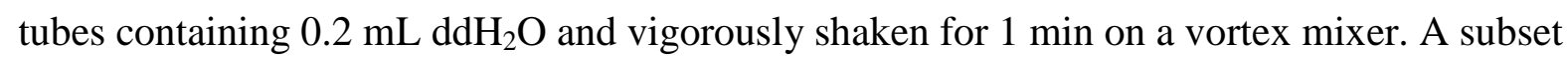

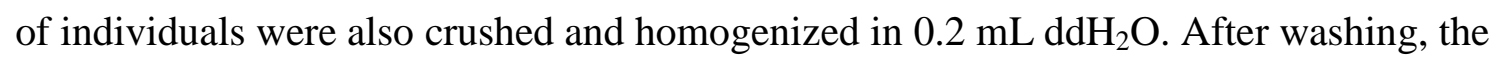
arthropods were removed (when not crushed) and stored in $70 \%$ ethanol for later identification. Water suspensions were spread on Petri dishes containing 2\% MEA, streptomycin sulphate $(0.04 \mathrm{~g} / \mathrm{L})$ and cycloheximide $(0.05 \mathrm{~g} / \mathrm{L})$. When present, a single colony 
of all the suspected Ophiostomatales morpho-types growing on these primary isolation plates was chosen at random and purified as representatives of the different fungal taxa. Once purified, all cultures were maintained on Petri dishes containing MEA at $4{ }^{\circ} \mathrm{C}$ until further use. Representative cultures of all morpho-types collected in this study are maintained in the culture collection (CMW) of the Forestry and Agricultural Biotechnology Institute (FABI) at the University of Pretoria, South Africa. Type material has been deposited in the herbarium of the National Collection of Fungi, Pretoria, South Africa (PREM) and the fungal collection of the Centraalbureau voor Schimmelcultures (CBS), Utrecht, The Netherlands.

\section{Morphological characterisation}

Where possible/available, fruiting structures (ascocarps with ascospores) of the Ophiostomatales taxa found in beetle galleries were collected and mounted in clear lactophenol on microscope slides. These were studied using a Leica EZ4 microscope (Leica Microsystems (Schweiz) AG, Taiwan). For isolates chosen as the types of new species, 25 measurements of all characteristic morphologically and taxonomically useful structures were made and the means ( \pm standard deviation) were calculated. A Leica digital camera mounted on the microscope was used to take photographs.

\section{DNA extraction, amplification and sequencing}

Three or more isolates from each beetle species and their galleries, representing each fungal morpho-type, were selected for DNA sequence comparisons (Table 1). Using a sterile scalpel, fungal mycelium was harvested from 2 wk old, actively growing colonies on MEA. Following the manufacturer's instructions, genomic DNA was extracted using a SigmaAldrich $^{\mathrm{TM}}$ plant extraction kit (USA). Preliminary placement of fungi into genera was done using nuclear ribosomal internal transcribed spacer region (ITS1, ITS2) and the 5.8S gene 
region of the rDNA (ITS), and according to this, amplification of other gene regions for specific clades were chosen based on previous studies (De Beer et al. 2013). Primers ITS1-f (Gardes and Bruns 1993) and ITS4 (White et al. 1990) were used to amplify ITS. In cases where amplification was difficult, ITS1-f was replaced with ITS1 (White et al. 1990). For DNA amplification, the reaction mixture for the Polymerase Chain Reaction (PCR) was 25 $\mu \mathrm{L}$, consisting of $11.3 \mu \mathrm{LddH} \mathrm{H}_{2} \mathrm{O}, 2 \mu \mathrm{L}$ DNA, $2.5 \mu \mathrm{L}$ 10X PCR reaction buffer (with $\mathrm{MgCl}_{2}$ ), $2.5 \mu \mathrm{L}$ deoxyribonucleotide triphosphate mix (dNTP) $(5 \mathrm{mM}), 5 \mu \mathrm{L}$ GC rich solution (Roche Applied Science, Mannheim, Germany), $0.5 \mu \mathrm{L}$ of each primer (10mM), $0.5 \mu \mathrm{L}$ extra $\mathrm{MgCl}_{2}$ (25mM) and 0.2 $\mu$ L FastStart Taq DNA Polymerase (Roche Applied Science, Mannheim, Germany).

For the relevant fungal morpho-types, primers T10 (O’Donnell and Cigelnik 1997) and Bt2b (Glass and Donaldson 1995) were used to amplify part of the Beta-tubulin (Bt) gene region and where amplification did not work, Bt2a (Glass and Donaldson 1995) replaced T10. CL2F and CL2R (Duong et al. 2012) were used for PCR for part of the Calmodulin (CAL) gene, and where amplification was difficult, either CL2R2 (Duong et al. 2012) was used in place of CL2R or a combination of the primers CL3F and CL3R was used. For the ribosomal LSU and SSU, primer pairs LR0R and LR5 (Vilgalys and Hester 1990), and NS1 and NS4 (White et al. 1990), were respectively used. The same PCR volumes used for ITS primers were used for DNA amplification of the other gene regions, except that no GC solution was added. PCR conditions comprised of an initial denaturation for $5 \mathrm{~min}$ at $95^{\circ} \mathrm{C}$, followed by 35 cycles of $30 \mathrm{~s}$ denaturation at $95^{\circ} \mathrm{C}, 30 \mathrm{~s}$ annealing at $55^{\circ} \mathrm{C}$ and $60 \mathrm{~s}$ elongation at $72{ }^{\circ} \mathrm{C}$. A final elongation step at $72^{\circ} \mathrm{C}$ for 8 min was performed before termination of the PCR process. In some cases the annealing temperature was lowered to 50 ${ }^{\circ} \mathrm{C}$ to enable amplification. The same PCR protocol was used for all markers and sequencing of fragments followed protocols described in Roets et al. (2006). 
Both DNA strands were sequenced using the same primers as those used for PCR amplifications. The CLC Genomics Workbench software package (CLC Bio, Cambridge, Massachusetts) was used to edit and combine sequences from both strands for each isolate to create consensus sequences. Sequences generated in this study (Table 1) were compared to sequences available from the GenBank sequence database (http://www.ncbi.nlm.nih.gov) and to those from the relevant clades identified in previous studies (De Beer et al. 2013). Alignment of sequences with those downloaded from GenBank was done online using MAFFT 6 (Katoh and Toh 2008) for each dataset. All datasets created were subjected to Bayesian inference (BI) and maximum likelihood (ML) analyses. ML analyses were performed with the online version of PhyML 3.0 (Guindon and Gascuel 2003, http://www.atgc-montpellier.fr/phyml). jModelTest 0.1.1 (Posada 2008) was used to determine the best fit substitution models using Akaike information criteria (Akaike 1974) and confidence support values for nodes were estimated using 1000 replication bootstrap analyses. Bayesian inference analyses were performed based on a Markov chain Monte Carlo approach (MCMC) using MrBayes v. 3.2 (Ronquist et al. 2012). MrBayes’s rjMCMC mixture model was used. Starting from a random tree, two Markov chains independent of each other were run simultaneously for 10 million generations. At every $2000^{\text {th }}$ generation, trees were sampled and burn-in trees (first 2500000 generations) were discarded. The remaining trees were pooled into a $50 \%$ majority rule consensus tree.

Growth in culture

The optimal growth conditions of suspected new species were determined using designated type cultures for taxa identified as undescribed. A disk of agar (10 mm diam) that was covered with mycelium was removed from the edges of actively growing 1 wk old cultures. They were placed mycelial side downward facing in the centres of $90 \mathrm{~mm}$ Petri dishes containing $20 \mathrm{~mL}$ MEA and incubated for $10 \mathrm{~d}$ in the dark at different temperatures ranging 
from $5{ }^{\circ} \mathrm{C}$ to $35^{\circ} \mathrm{C}$ at intervals of $5{ }^{\circ} \mathrm{C}$. For each temperature interval, five replicates were used. Two colony diameters perpendicular to each other were taken after incubation and averaged for each isolate and means and standard deviations for each fungal species were calculated.

\section{Results}

\section{Beetles}

Three Scolytinae and one Platypodinae species were collected from $R$. melanophloeos and $O$. capensis ssp. macrocarpa trees. All were associated with members of the Ophiostomatales. Lanurgus sp. 1 Eggers and Ctonoxylon sp. 1 Hagedorn (Scolytinae) were both collected from O. capensis ssp. macrocarpa, while Xyleborinus aemulus Wollaston (Scolytinae) and the Platypodinae species were collected only from R. melanophloeos. About 2000 individuals of Lanurgus sp. 1, 300 individuals of Ctonoxylon sp. 1, six individuals of X. aemulus and only three individuals of the Platypodinae species were collected.

Fungal isolates and morphological characterisation

A total of 38 fungal isolates that morphologically resembled members of the Ophiostomatales were obtained from the four beetle species. Of these, 15 were isolated from Lanurgus sp. 1, 10 from Ctonoxylon sp. 1, eight from X. aemulus and five from the Platypodinae species. Based on micro-morphology and colony characteristics, these isolates were grouped into four different operational taxonomic units (OTUs). The first OTU came from Lanurgus sp. 1 from O. capensis ssp. macrocarpa and had a reduced hyalorhinocladiella-like anamorph and ascomata with sheathed, ossiform ascospores (Type E) (De Beer and Wingfield 2013). The Platypodinae beetle from $R$. melanophloeos was associated with the second OTU with only 
an asexual state with inflated conidia resembling those produced by species in the genus Raffaelea. Xyleborinus aemulus, collected from $R$. melanophloeos, was associated with a third OTU with a sporothrix-like asexual state and ascomata with ascospores (Type A) resembling those of species in the $S$. schenckii-O. stenoceras- complex (De Beer and Wingfield 2013). The fourth OTU also had an asexual state that resembled those of Sporothrix spp. and was associated with both Lanurgus sp. 1 and Ctonoxylon sp. 1 collected from $O$. capensis ssp. macrocarpa.

Phylogenetic analyses

ITS data confirmed the ordinal placement of all four of the collected fungal OTUs in the Ophiostomatales. The phylogenetic placement of the OTUs with the hyalorhinocladiella- and raffaelea-like asexual states was determined using LSU and ITS data (ITS dat set I). The aligned LSU data set included 106 taxa and 750 characters, while the ITS data set I included 53 taxa and 701 characters. Statistical values obtained from analyses of the different data sets and the substitution models chosen are presented in Supplementary resource 1. Both the LSU (Fig. 1) and ITS (Fig. 2) data showed that these two taxa grouped in Raffaelea s. str., but distinct from all the known species in this group. Hereafter these two taxa are referred to as $R$. vaginata sp. nov. and $R$. rapaneae sp. nov.

ITS data of the remaining two OTUs with sporothrix-like anamorphs suggested that these two taxa belonged to the S. schenckii-O. stenoceras complex in Ophiostoma s.l. as defined by De Beer and Wingfield (2013). Since ITS data between the different genera in the Ophiostomatales vary too much to reliably align in a single data set (De Beer and Wingfield 2013), the ITS data of these two OTUs were not included in the same data set as the Raffaelea spp. They were instead included in a second ITS data set (ITS data set II) that had reference sequences of species in the S. schenckii-O. stenoceras complex (data not shown). 
The phylogenetic placement of these two OTUs were further investigated using $\beta T$ and CAL sequences. The aligned ITS data set II consisted of 54 taxa and 723 characters, the $\beta$ T data set consisted of 45 taxa and 276 characters, while the CAL data set contained 38 taxa and 684 characters. Analyses of ITS (data set II, tree not shown), $\beta$ T (Fig. 3) and CAL (Supplementary resource 2) data showed that the sporothrix-like OTU associated with Lanurgus sp. 1 and Ctonoxylon sp. 1 on O. capensis ssp. macrocarpa grouped in a clade with strong support that included the ex-type isolates of Sporothrix pallida (Tubaki) Matsushima and its synonyms $S$. albicans S.B. Saksena and S. nivea Kreisel \& F. Schauer (De Meyer et al. 2008). The other sporothrix-like OTU from Xyleborinus aemulus on R. melanophloeos (hereafter referred to as: Sporothrix aemulophila sp. nov.) grouped strongly as distinct, but sister to Ophiostoma candidum Kamgan-Nkuek., Jol. Roux \& Z. W. de Beer, using the same three markers (Fig. 3 and Supplementary resource 2). All data matrices and Bayesian $50 \%$ majority-rule consensus trees are available from Treebase (http://treebase.org/treebaseweb/search/study/summary.html?id=17791).

Growth in culture

After $10 \mathrm{~d}$ of growth in the dark, $R$. vaginata sp. nov. grew optimally at $30^{\circ} \mathrm{C}$, with a mean colony diameter of $23.8 \mathrm{~mm}( \pm 1.3)$. Raffaelea rapaneae sp. nov. had a colony diameter of 21 $\mathrm{mm}( \pm 0.95)$ when grown at its optimal temperature of $20^{\circ} \mathrm{C}$ and $S$. aemulophila sp. nov. had a mean colony diameter of $24.2 \mathrm{~mm}( \pm 1.4)$ at an optimal temperature of $30^{\circ} \mathrm{C}$.

\section{Taxonomy}

Based on micro-morphological and phylogenetic analyses three of the four collected taxa are recognised as distinct and undescribed taxa. Two of the novel species grouped in the genus Raffaelea and are described here. One of these presented a sexual state in culture and thus the 
generic description of Raffaelea is emended below, as the genus to date only accommodated species known from the asexual states. Furthermore, our analyses confirmed the placement of two Ophiostoma spp. with sexual states in the genus Raffaelea, and new combinations are provided for these two taxa. The other two taxa isolated in the present study belonged to the S. schenckii-O. stenoceras complex. The one was identified as S. pallida and the other as a new species, described below.

Raffaelea Arx \& Hennebert, Mycopathol. Mycol. Appl. 25: 310.1965. emend. Z.W. de Beer \& T.A. Duong. [type species R. ambrosiae Arx \& Hennebert, Mycopathol. Mycol. Appl. 25: 310.1965.]

Ascocarps light brown to black, bases globose to subglobose; necks dark brown to black, slightly bulbous to cylindrical to tapered, straight or slightly curved; ostiolar hyphae present or absent. Asci evanescent. Ascospores hyaline, aseptate, cylindrical to oblong, surrounded with a hyaline, gelatinous, ossiform to rectangular sheath. Conidiophores single to aggregated in sporodochia, hyaline, unbranched or sparingly branched, one-celled to septate, producing conidia holoblastically. Conidiogenous cells proliferating percurrently or sympodially, leaving denticles, inconspicuous scars, or annellations. Conidia hyaline, elliptical to ovoid to globose, sometimes T- or Y-shaped, succession schizolytic, producing yeast-like growth through budding. Tolerating cycloheximide in culture. Phylogenetically classified in the Ophiostomatales. Associated with ambrosia beetles.

Notes: Harrington et al. (2010) emended the generic description of Raffaelea to accommodate asexual ambrosial species in the Ophiostomatales. De Beer and Wingfield (2013) and Dreaden et al. (2014) showed that Raffaelea is not monophyletic as was suggested by Harrington et al. (2010). De Beer and Wingfield (2013) also showed that two Ophiostoma species with similar sexual states, $O$. seticolle (R.W. Davidson) de Hoog \& Scheffer, and $O$. deltoideosporum (Olchow. \& J. Reid) Hausner, J. Reid \& Klassen, grouped among Raffaelea 
s. str. isolates, but were hesitant to include these species in Raffaelea. The discovery in the present study of yet another species that produces sexual structures with ascospores similar to those of $O$. seticolle and $O$. deltoideosporum, confirmed that the genus Raffaelea does not only consist of asexual species as was previously considered (Cassar and Blackwell 1996; Alamouti et al. 2009; Harrington et al. 2010). Based on the one fungus one name principles recently adopted into the International Code of Nomencalture for Algae, Fungi and Plants (Hawksworth 2011; Hawsworth et al. 2011), we here emend the generic diagnosis of Raffaelea. We largely followed the emended description for Raffaelea by Harrington et al. (2010) for the asexual forms produced in the genus, and based the diagnosis of the sexual states on the protologues of three species producing sexual states. We furthermore provide new combinations for $O$. seticolle and $O$. deltoideosporum in Raffaelea.

Raffaelea seticolle (R.W. Davidson) Z.W. de Beer \& T.A. Duong comb. nov., MycoBank: MB813625

$\equiv$ Ceratocystis seticollis R.W. Davidson, Mycopath. Mycol. Appl. 28: 282. 1966. (basionym) $\equiv$ Ophiostoma seticolle (R.W. Davidson) de Hoog \& Scheffer, Mycologia 76: 297. 1984. Descriptions: Davidson (1966, pp. 282-285, Figs 4-5); Upadhyay (1981, p. 83, Figs 286289).

Notes: This species was originally isolated from ambrosia galleries in a hemlock (Tsuga canadensis) stump in New York State (Davidson 1966) and, to our knowledge, never reported again. The LSU sequence produced for the ex-type isolate of this species by Hausner and Reid (2003), placed this species peripheral to other Ophiostoma spp. but no Raffaelea spp. were included in their analyses. In the more comprehensive data set analysed by De Beer and Wingfield (2013), the species grouped in Raffaelea s. str. However, they treated the species as of uncertain generic status (De Beer and Wingfield 2013; De Beer et al. 2013) 
because an ITS sequence produced by Jacobs et al. (2003) grouped in the S. schenckii-O. stenoceras complex. The latter sequence was clearly erroneous as the morphology of the sexual and asexual states, as well as its ambrosial habit, supports its placement in Raffaelea s. str. as confirmed by the LSU sequence of Hausner and Reid (2003). Attempts to revive the ex-holotype isolate of $C$. seticolle for more DNA sequences were not successful, so the only reliable and usable sequence for this species is the one produced by Hausner and Reid (2003).

Raffaelea deltoideospora (Olchow. \& J. Reid) Z.W. de Beer \& T.A. Duong comb. nov., MycoBank: MB813626

$\equiv$ Ceratocystis deltoideospora Olchow. \& J. Reid, Can. J. Bot. 52: 1691. 1974. (basionym) $\equiv$ Ophiostoma deltoideosporum (Olchow. \& J. Reid) Hausner, J. Reid \& Klassen, Can. J. Bot. 71: 1264. 1993.

Descriptions: Olchowecki and Reid (1974, pp. 1691-1692, Figs 132-141); Upadhyay (1981, p. 77-78, Figs 253-256).

Notes: This species was originally isolated from Pinus banksiana, P. resinosa and P. strobus wood in Manitoba and Ontario, Canada (Olchowecki and Reid 1974), and subsequently from cerambycid pupal chambers in $P$. resinosa and $P$. banksiana in Wisconsin, USA (Wingfield 1987). However, the latter identification was based on morphology only. The LSU sequence of this species grouped peripheral to Ophiostoma s.1. and Leptographium s.l. in the analyses of Hausner et al. (1993) and Hafez et al. (2013), but no Raffaelea spp. were included in those studies. The analyses of De Beer and Wingfield (2013) and our results (Fig. 1) showed that this species groups in Raffaelea s. str. based on LSU data. Similarly, based on the study of De Beer and Wingfield (2013) and on our results (Fig. 2), the ITS sequence (Mullineux and Hausner 2009) grouped in a lineage with $R$. canadensis, the only species of Raffaelea s. str. for which ITS sequence data is currently available. The hyalorhinocladiella-like 
conidiogenesis and ossiform ascospores resemble those of both $R$. seticolle and $R$. scabbardiae, and validate its treatment in Raffaelea s. str.

Raffaelea vaginata T. Musvuugwa, Z.W. de Beer, L.L. Dreyer \& F. Roets sp. nov. Fig. 4b-g. Mycobank: MB812910.

Etymology: The epithet vaginata is derived the Latin vagina, meaning a sheath or covering, and refers to the sheathed ascospores produced by this species.

Ascomata superficial on the host substrate, bases globose, black, with no hyphal ornamentation, (85-) 92-142 (-149) $\mu \mathrm{m}$ diam, necks black, (308-) 311-692 (-698) long, (19-) 24-40 (-45) $\mu \mathrm{m}$ wide at base, (4-) 10-18 (-23) $\mu \mathrm{m}$ wide at the apex, osteolar hyphae absent (Fig. 4b and 4c). Asci evanescent. Ascospores cylindrical, aseptate, hyaline, sheaths present, (1.5-) 2.3-3.4 (-3.8) × (0.3-) 0.8-1.5 (-1.9) $\mu \mathrm{m}$ (Fig. 4d), accumulating in a gelatinous droplet at the tip of the neck, becoming white to cream colored when dry. Colonies white to cream coloured on MEA. Odourless, circular with entire edge and rough surface (Fig. 4e). Colony diameter reaching $23.8 \mathrm{~mm}( \pm 1.3)$ after $10 \mathrm{~d}$ of growth on MEA at optimal growth temperature of $30^{\circ} \mathrm{C}$ in the dark. No growth below $10^{\circ} \mathrm{C}$ or above $35^{\circ} \mathrm{C}$.

Conidiophores hyaline, (6.6-) 7.1-8.9 (-9.2) $\mu \mathrm{m}$ long, (0.3-) 0.7-1.1 (-1.5) $\mu \mathrm{m}$ wide (Fig. 4f), Conidiogenous cells forming directly from apex of conidiophores, hyaline, (Fig. 4f), Conidia produced sympodialy, aseptate, hyaline, thick walled, obovate, (3-) 3.5-4.9 (-5.4) $\mu \mathrm{m}$ long, (0.4-) 0.7-1.1 (-1.8) $\mu \mathrm{m}$ wide (Fig. 4f-g). Conidia produced singly, directly from hyphae (Fig. 4f-g).

Substrate: Isolated from Lanurgus sp. 1 (Scolytinae) (Fig. 4a) and its host plant Olea capensis ssp. macrocarpa.

Distribution: South Africa, Western Cape Province 
Specimens examined: South Africa, Western Cape Province, Gouldveld and Gourna forest. Isolated from Lanurgus sp. associated with Olea capensis, October 2011, T. Musvuugwa, holotype PREM 61274, culture ex-holotype CMW 40365 = CBS 140086, paratype PREM 61273, culture ex-paratype CMW 40363, paratype culture ex-paratype CMW 40366.

Raffaelea rapaneae T. Musvuugwa, Z.W. de Beer, L.L. Dreyer and F. Roets sp. nov. Fig. 5be.

Mycobank: MB812911.

Etymology: The epithet rapaneae refers to the host plant genus (Rapanea melanophloeos) from which this species was collected.

Ascomata not observed. Colonies cream turning blackish on MEA, odourless, surface tough and leathery, which wrinkles and forms cracks under the wrinkled area (Fig. 5b). Colony diameter reaching $21 \mathrm{~mm}$ after $10 \mathrm{~d}$ on MEA at $20^{\circ} \mathrm{C}$. Optimal growth at $20^{\circ} \mathrm{C}$. No growth below $10^{\circ} \mathrm{C}$ or above $25^{\circ} \mathrm{C}$, cream in the center and black along the edges, somewhat circular with rough surface and edge. Conidiophores hyaline, tapering towards the tips, with segmented appearance, (9.9-) 10.6-15.5 (-17.5) $\mu \mathrm{m}$ long, (1-) 1.5-1.7 (-2.1) $\mu \mathrm{m}$ wide (Fig. 5c-e), Conidiogenous cells phialidic, arising from tips of conidiophores, hyaline (Fig. 5d-e), Conidia aseptate, hyaline, turning brown when mature, thick walled, spherical, form in masses, (1.6-) 2.3-3.5 (-4.3) $\mu \mathrm{m}$ long, (1.7-) 2.4-3.4 (-3.9) $\mu \mathrm{m}$ wide (Fig. 5c-e). Substrate: Isolated from a Platypodinae beetle (Fig 5a) collected from the wood of Rapanea melanophloeos

Distribution: South Africa, Western Cape Province Specimens examined: South Africa, Western Cape Province, Gourna forest. Isolated from Platypodinae sp. associated with Rapanea melanophloeos, February 2012, T. Musvuugwa, holotype PREM 61271, culture ex-holotype CMW 40357 = CBS 140084, paratype PREM 
61272, culture ex-paratype CMW 40359 = CBS 140085, paratype culture ex-paratype CMW 40357.

Sporothrix aemulophila T. Musvuugwa, Z.W. de Beer, L.L. Dreyer \& F. Roets sp. nov. Fig. 6b-g.

Mycobank: MB812912.

Etymology: The epithet aemulophila refers to the apparent close association between this species and the beetle Xyleborinus aemulus.

Ascomata embedded in and superficial on the host substrate, bases black, globose, (72-) 81$162(-170) \mu \mathrm{m}$ diam, hyphal ornamentation absent. Ascomatal necks black, (270-) 278-743 (-750) $\mu \mathrm{m}$ long, (18-) 22-45 (-51) $\mu \mathrm{m}$ wide at base, (4-) 7-11 (-13) $\mu \mathrm{m}$ wide at the tip (Fig. 6b), osteolar hyphae present, slightly curved, hyaline, (9-) 13-20 (-24) $\mu \mathrm{m}$ long (Fig. 6c). Asci evanescent. Ascospores allantoid, aseptate, hyaline, sheaths absent, (2-) 2.9-4.5 ($5.5) \times(0.2-) 0.9-1.3(-1.8) \mu \mathrm{m}$ (Fig. 6d), accumulating in a sticky droplet at the tip of the neck, becoming whitish when dry. Colonies of sporothrix-like asexual state whitish in colour on MEA, odourless, circular with entire edge and fluffy (Fig. 6e). Colony diameter reaching $24.2 \mathrm{~mm}( \pm 1.4)$ after $10 \mathrm{~d}$ of growth on MEA at an optimum growth temperature of $30^{\circ} \mathrm{C}$ in the dark. No growth below $5^{\circ} \mathrm{C}$ or above $35^{\circ} \mathrm{C}$. Conidiophores hyaline, tapering towards the tip, (3.8-) 4.5-8.2 (-8.7) $\mu \mathrm{m}$ long, (0.3-) 0.8-1.2 (-1.8) $\mu \mathrm{m}$ wide (Fig. 6f), Conidiogenous cells forming directly from tips of conidiophores, hyaline, prominent denticles present (0.3-) 0.6-1.4 (-1.7) $\mu \mathrm{m}$ long (Fig. 6f). Conidia produced sympodialy, hyaline, aseptate, oblong, holoblastic, (3.2-) 3.8-7.2 (-7.6) $\mu \mathrm{m}$ long, (0.4-) 0.9-1.5 (-1.9) $\mu \mathrm{m}$ wide (Fig. 6g). Substrate: Isolated from Xyleborinus aemulus (Fig. 6a) and its galleries on Rapanea melanophloeos

Distribution: South Africa, Western Cape Province 
Specimens examined: South Africa, Western Cape Province, Harold Porter National Botanical Garden. Isolated from Xyleborinus aemulus associated with Rapanea melanophloeos April, 2010, T. Musvuugwa, holotype PREM 61275, culture ex-holotype CMW 40381 = CBS 140087, paratype PREM 61276, culture ex-paratype CMW $40382=$ CBS 140088, paratype culture ex-paratype CMW 40383.

\section{Discussion}

This represents the first study on the Ophiostomatales associated with sub-cortical beetles from trees native to the Afromontane forests of the CFR, South Africa. Previous studies focussed on either those taxa associated with wounds on native trees (e.g. Kamgan Nkuekam et al. 2008) or on the beetle associates of exotic tree taxa (e.g. Zhou et al. 2001). Three species from two genera were newly described here from only four beetle species occurring on two tree species. Considering the large diversity of native plants, bark beetles and ambrosia beetles associated with these forests, it is reasonable to assume that many taxa still await discovery. This study therefore forms a platform for future studies on the diversity, evolution and ecology of these important fungi. In addition, this study placed three species with sexual states in Raffaelea, which had previously contained only asexual taxa.

The two Raffaelea species collected in this study group with members of the Raffaelea s. str. clade (De Beer and Wingfield 2013). Although the two species group in different clades within Raffaelea s. str., they are closely related. Most of the species in Raffaelea s. str. are associated with ambrosia beetles (Harrington et al. 2010; De Beer and Wingfield 2013). This was also found to be the case with the two Raffaelea species collected here. Morphologically they generally exhibit hyalorhinocladiella-like asexual states and reduced conidiogenous structures, often producing pigmented conidia (De Beer et al. 2013). Only a few other Raffaelea species have been reported from South Africa. These include $R$. 
albimanens D.B. Scott \& J.W. du Toit, which was associated with the ambrosia beetle $P$. externedentatus Fairm. from Ficus sycomorus L. in the Dukuduku Forest in the KwazuluNatal Province, and R. arxii D.B. Scott \& J.W. du Toit, associated with Xyleborus torquatus Eichh. and collected from Schefflera (=Cussonia) umbellifera (Sond.) Baill. (Scott and Du Toit 1970).

Raffaelea vaginata was associated with the ambrosia beetle Lanurgus sp. 1 from Olea capensis ssp. macrocarpa and represents the first report of any Ophiostomatales from both the beetle and host tree. Although part of Raffealea s. str., it is phylogenetically and morphologically very distinct from the other species in the genus. Although most of the species in the Raffaelea s. str. clade are associated with ambrosia beetles, $R$. vaginata is the first species in the group that is associated with a beetle in the genus Lanurgus.

Raffaelea rapaneae was isolated from a Platypodinae beetle associated with $R$. melanophloeos. Phylogenetically it clearly belongs in the genus, but is also very distinct from all the other known species. Similar to the beetle associate of $R$. rapanaea, the associates of many other Raffaelea species belong to the subfamily Platypodinae. Raffaelea ambrosiae Arx \& Hennebert, for example, is associated with Platypus cylindricus Fab. and P. compositus Say (Baker 1963, Batra 1967), R. santoroi Guerrero is associated with P. sulcatus Chap. (Guerrero 1966), and the South African R. albimanens is associated with P. externedentatus (Scott and du Toit 1970).

Both the Sporothrix species collected in this study belong to the S. schenckii-O. stenoceras complex, which forms part of a larger contingent, Ophiostoma sensu lato (De Beer and Wingfield 2013). Besides the human pathogens, such as S. schenckii and S. luriei, the $S$. schenckii-O. stenoceras complex mostly contains species that are associated with environmental samples such as soil (De Meyer et al. 2008). However, some species in this complex are arthropod-associated. Examples include nine species collected from Protea 
infructescences in Southern Africa, two of which have been confirmed to be specifically associated with mites (Roets et al. 2007, 2009). Other species that have been isolated infrequently from bark beetles infesting Pinus spp. include O. aurorae X.D. Zhou \& M.J. Wingf. (Zhou et al. 2006), O. cantabriense P. Romón, Z.W. De Beer \& M.J. Wingf. (Romón et al. 2014a), O. euskadiense P. Romón, Z.W. De Beer \& M.J. Wingf. (Romón et al. 2014b), O. abietinum Marm. \& Butin and O. abietinum-like isolates (Zhou et al. 2004, 2006; Linnakoski et al., 2010; Taerum et al. 2013). Given the number of South African species in this complex, it has been suggested that southern Africa may be the centre of diversity for this group of fungi (Kamgan Nkuekam et al. 2012).

Our isolates of S. pallida were collected from both Lanurgus sp. 1 and Ctonoxylon sp. 1. Sporothrix pallida is known from many environmental habitats (e.g. water sediments, soil and the sporophore of a slime-mould) and from various European countries (e.g. Germany, Spain, Italy, Netherlands, and England) as well as Japan (De Meyer et al. 2008). This fungus was also recently isolated from a human patient as the causative agent of a corneal ulcer (Morrison et al. 2013). To the best of our knowledge our findings represent the first example of this fungus in association with Scolytinae beetles. It is also the first example of a member of the Ophiostomatales associated with beetles belonging to the genera Lanurgus and Ctonoxylon.

Similar to S. pallida, the newly described S. aemulophila was associated with a Scolytinae beetle, Xyleborinus aemulus. It is closely related to $O$. candidum that is associated with a cerambycid beetle on exotic Eucalyptus spp. trees in South African plantations (Kamgan Nkuekam et al. 2012). Sporothrix aemulophila and O. candidum differ in many characteristics, including optimal growth temperature $\left(30^{\circ} \mathrm{C}\right.$ for $S$. aemulophila and $25^{\circ} \mathrm{C}$ for O. candidum), ornamentation at the base of ascoma (present in $O$. candidum and absent in $S$. aemulophila) and dimensions of morphological characters (Kamgan Nkuekam et al. 2012). 
Despite quite extensive surveys from wounds on trees in the Afromontane forests where $S$. aemulophila occurs, including those on the same $R$. melanophloeos host, this species has never been found previously (Kamgan Nkuekam et al. 2008). Whether this fungus is involved in beetle nutrition is unknown, but the beetle has an ambrosial-type of tunnelling system, which is usually seen in beetle taxa that depend on fungi for survival (De Fine Licht and Biedermann 2012; Jordal and Cognato 2012). Xyleborinus saxesenii, an ambrosia beetle in the same genus as $X$. aemulus, is mutualistically associated with fungi in the Ophiostomatales (Biedermann 2012). This suggests that the association between $X$. aemulus and $S$. aemulophila may be mutualistic, but this needs to be confirmed in future studies.

The beetle species collected in this study were mostly associated with recently dead trees, although they were collected from weakened living trees in a few cases. These beetles can therefore be classified as secondary beetles, known to attack stressed, weakened and recently dead trees (Paine et al. 1997; Six and Wingfield 2011; Avtzis et al. 2012). Although secondary beetles have been responsible for the destruction of large populations of stressed trees (for example Breshears et al. 2005), we have seen no evidence of this at the sites included in this study.

Four members of the order Ophiostomatales were collected in this study from four subcortical beetles infesting $R$. melanophloes and $O$. capensis ssp. macrocarpa. This represents the first report of subcortical beetles associated with the Ophiostomatales in the CFR. Phylogenetic analyses confirmed that one new species belongs to the S. schenckii-O. stenoceras complex, while two other new species belong to Raffaelea s. str. Given that three out of the four fungal species collected are new species, it is highly likely that there are more Ophiostomatales beetle-associates awaiting discovery in the CFR. Future research should include other native tree taxa and sub-cortical beetles. Although this study was an important first step towards understanding relationships between subcortical beetles and their fungal 
symbionts on native trees in the CFR, the exact nature of these relationships are still unclear and needs to be a focus in future studies.

Acknowledgments The authors thank the DST/NRF Centre of Excellence in Tree Health Biotechnology (CHTB) for financial support and the South African National Parks Board (SANPARKS) and Western Cape Nature Conservation Board for issuing the necessary collecting permits. We are also grateful to Netsai Machingambi, PC Benade and Dewidine van der Colff for assistance with field work and Jane Forrester for permission to work on trees in the Harold Porter National Botanical Garden. Special thanks to Michail Mandelshtam for identification of the beetles collected in this study.

\section{Conflict of interest None.}

\section{References}

Akaike H (1974) A new look at the statistical model identification. IEEE Trans Autom Control 19:716-723

Alamouti SM, Tsui CKM, Breuil C (2009) Multigene phylogeny of filamentous ambrosia fungi associated with ambrosia and bark beetles. Mycol Res 113:822-835

Atkinson TH, Peck SB (1994) Annotated checklist of the bark and ambrosia beetles (Coleoptera: Platypodidae and Scolytidae) of tropical southern florida. Fla Entomol 77:313329

Atkinson TH, Equihua A (1986) Source biology of the scolytidae and platypodidae (Coleoptera) in a tropical deciduous forest at Chamela, Jalisco, Mexico. Fla Entomol 69:303310

Avtzis DN, Bertheau C, Stauffer C (2012) What is next in bark beetle hylogeography? Insects $3: 453-472$

Baker JM (1963) Ambrosia beetles and their fungi with particular reference to Platypus cylindrus Fab. In: Nutman PS and Mosse B (eds) Symbiotic associations, 13th Symposium, Society for General Microbiology, Cambridge University Press, Cambrage, pp. 232-265 
Barras SJ, Perry TJ (1972) Fungal symbionts in the prothoracic mycangium of Dendrocfonus frontalis. Z Angew Entomol 7:95-104

Batra LR (1966) Ambrosia fungi: extent of specificity to ambrosia beetles. Science 153:193195

Batra LR (1967) Ambrosia fungi: a taxonomic revision, and nutritional studies of some species. Mycologia 59:976-1017

Beaver AR (1989) Insect-fungus relationships in the bark and ambrosia beetles. In: Wilding N, Collins NM, Hammond PM and Webber JF (eds) Insect-fungus interactions, Academic Press, United Kingdom, pp. 121-143

Beaver AR (2005) A remarkable new species of Cyclorhipidion hagedorn, and new records of bark and ambrosia beetles from Gabon (Coleoptera: Curculionidae, Scolytinae and Platypodinae). Entomologist's monthly magazine 141:113-119

Beaver AR, Liu L-Y (2013) A synopsis of the pine-hole borers of Thailand (Coleoptera: Curculionidae: Platypodinae). Zootaxa 3646:447-486

Berryman AA (1972) Resistance of conifers to invasion by bark beetle fungus associations. Bioscience 22:598-602

Biedermann PHW (2012) Evolution of cooperation in ambrosia beetles. Dissertation, University of Bern

Brasier CM (2000) Intercontinental spread and continuing evolution of the Dutch elm disease pathogens. In: Dunn CP (ed) The elms: breeding, conservation and disease management, Kluwer Academic Publishers, USA, pp. 61-72

Brasier CM, Buck KW (2001) Rapid evolutionary changes in a globally invading fungal pathogen (Dutch elm disease). Biol Invasions 3:223-233

Breshears DD, Cobb NS, Rich PM, Price KP, Allen CD, Balice RG, Romme WH, Kastens JH, Floyd ML, Belnap J, Anderson JJ, Myers OB, Meyer CW (2005) Regional vegetation die-off in response to global-change-type drought. P Natl Acad Sci USA 102:15144-15148

Bridges JR, Moser JC (1983) Role of two phoretic mites in transmission of bluestain fungus, Ceratocystis minor. Ecol Entomol 8:9-12

Browne FG (1968) Pests and diseases of forest plantation trees. Clarendon Press, Oxford

Cassar S, Blackwell M (1996) Convergent origins of ambrosia fungi. Mycologia 88:596-601

Chen SF, Wingfield MJ, Roets F, Roux J (2013) A serious canker disease caused by Immersiporthe knoxdaviesiana gen. et sp. nov. (Cryphonectriaceae) on native Rapanea in South Africa. Plant Pathol 62:667-678

Davidison RW (1966) New species of Ceratocystis from conifers. Mycopath Mycol Appl 28:273-286 
De Beer ZW, Wingfield MJ (2013) Emerging lineages in Ophiostomatales. In: Seifert KA, De Beer ZW and Wingfield MJ (eds) Ophiostomatoid fungi: expanding frontiers, CBS Biodiversity Series 12, pp. 21-46

De Beer ZW, Seifert KA, Wingfield MJ (2013) A nomenclature for ophiostomatoid genera and species in the Ophiostomatales and Microascales. In: Seifert KA, De Beer ZW and Wingfield MJ (eds) Ophiostomatoid fungi: expanding frontiers, CBS Biodiversity Series 12, pp. 245-322

De Fine Licht HH, Biedermann PHW (2012) Patterns of functional enzyme activity in fungus farming ambrosia beetles. Front Zool 9:13

De Meyer EM, De Beer ZW, Summerbell RC, Moharram AM, De Hoog GS, Vismer HF, Wingfield MJ (2008) Taxonomy and phylogeny of new wood- and soil-inhabiting Sporothrix species in the Ophiostoma stenoceras-Sporothrix schenckii complex. Mycologia 100:647-661

Dreaden TJ, Davis JM, De Beer ZW, Ploetz RC, Soltis PS, Wingfield MJ, Smith JA (2014) Phylogeny of ambrosia beetle symbionts in the genus Raffaelea. Fungal Biol 118:970-978

Duong T A, De Beer ZW, Wingfield BD, Wingfield MJ (2012) Phylogeny and taxonomy of species in the Grosmannia serpens complex. Mycologia 104:715-732

Farrell BD, Sequeira AS, O’Meara BC, Normark BB, Chung JH, Jordal BH (2001) The evolution of agriculture in beetles (Curculionidae: Scolytinae and Platypodinae). Evolution 55:2011-2027

Gardes M, Bruns TD (1993) ITS primers with enhanced specificity for basidiomycetes application to the identification of mycorrhizae and rusts. Mol Ecol 2:113-118

Glass NL, Donaldson GC (1995) Development of primer sets designed for use with the PCR to amplify conserved genes from filamentous Ascomycetes. Appl Environ Microbiol 61:1323-1330

Guerrero RT (1966) Una nueva especie de hongo inperfecto asociado con el coleoptero Platypus sulcatus Chapius. Revista de Investigciones Agropecuarias Series 3:97-103

Guindon S, Gascuel O (2003) A simple, fast, and accurate algorithm to estimate large phylogenies by maximum likelihood. Syst Biol 52:696-704

Hafez M, Majer A, Sethuraman J, Rudski SM, Michel F, Hausner G (2013) The mtDNA rns gene landscape in the Ophiostomatales and other fungal taxa: Twintrons, introns, and intronencoded proteins. Fungal Genet Biol 53:71-83

Harrington TC (1993) Biology and taxonomy of fungi associated with bark beetles. In: Schowalter TD and Filip GM (eds) Beetle-pathogen interactions in conifer forests, Academic Press, NY, pp. 37-58 
Harrington TC (2005) Ecology and evolution of mycophagous bark beetles and their fungal partners. In: Vega FE and Blackwell M (eds) Insect-Fungal Associations: Ecology and Evolution, Oxford University Press, New York, pp. 1-22

Harrington TC, Aghayeva DN, Fraedrich SW (2010) New combinations in Raffaelea, Ambrosiella, and Hyalorhinocladiella, and four new species from the redbay ambrosia beetle, Xyleborus glabratus. Mycotaxon 111:337-361

Harrington TC, Fraedrich SW, Aghayeva DN (2008) Raffaelea lauricola, a new ambrosia beetle symbiont and pathogen on the Lauraceae. Mycotaxon 104:399-404

Hausner G, Reid J (2003) Notes on Ceratocystis brunnea and some other Ophiostoma species based on partial ribosomal DNA sequence analysis. Can J Botany 81:865-876

Hausner G, Reid J, Klassen GR (1993) On the phylogeny of Ophiostoma, Ceratocystis s.s., and Microascus, and relationships within Ophiostoma based on partial ribosomal DNA sequences. Can J Botany 71:1249-1265

Hawksworth DL (2011) A new dawn for the naming of fungi: impacts of decisions made in Melbourne in July 2011 on the future publication and regulation of fungal names. MycoKeys $1: 7-20$

Hawksworth DL, Crous PW, Redhead SA, et al. (2011) The Amsterdam Declaration on Fungal Nomenclature. IMA Fungus 2:105-112

Heybroek HM (1993) Why bother about the elm? In: Sticklen MB and Sherald JL (eds) Dutch ElmDisease Research, Cellular and Molecular Approaches, Springer-Verlag, New York, pp. 1-8

Jacobs K, Seifert KA, Harrison KJ, Kirisits T (2003) Identity and phylogenetic relationships of ophiostomatoid fungi associated with invasive and native Tetropium species (Coleoptera: Cerambycidae) in Atlantic Canada. Can J Botany 81:316-329

Jacobs K, Wingfield MJ (2001) Leptographium species: Tree pathogens, insect associates, and agents of blue-stain. APS press, U.S.A.

Jordal BH, Cognato AI (2012) Molecular phylogeny of bark and ambrosia beetles reveals multiple origins of fungus farming during periods of global warming. BMC Evol Biol 12:133

Jordal BH, Beaver RA, Kirkendall LR (2001) Breaking taboos in the tropics: inbreeding promotes colonization by wood-boring beetles. Global Ecol Biogeogr 10:345-357

Kamgan Nkuekam G, De Beer ZW, Wingfield MJ, Roux J (2012) A diverse assemblage of Ophiostoma species, including two new taxa on eucalypt trees in South Africa. Mycol Progr 11:515-533

Kamgan Nkuekam G, Jacobs K, De Beer ZW, Wingfield MJ, Roux J (2008) Ceratocystis and Ophiostoma species including three new taxa, associated with wounds on native South African trees. Fungal Divers 29:37-59 
Katoh K, Toh H (2008) Recent developments in the MAFFT multiple sequence alignment program. Brief Bioinform 9:286-298

Klepzig KD, Six DL (2004) Bark beetle-fungal symbiosis: context dependency in complex associations. Symbiosis 37:189-205

Klepzig KD, Moser JC, Lombardero FJ, Hofstetter RW, Ayres MP (2001) Symbiosis and competition: Complex interactions among beetles, fungi and mites. Symbiosis 30:83-96

Knižek M, Beaver R (2004) Taxonomy and Systematics of Bark and Ambrosia Beetles. In: Lieutier F, Day KR, Battisti A, Grégoire J-C and Evans HF (eds) Bark and Wood Boring Insects in Living Trees in Europe, a Synthesis, Kluwer Academic Publishers, The Netherlands, pp. 41-54

Kubono T, Ito S (2002) Raffaelea quercivora sp. nov. associated with mass mortality of Japanese oak, and the ambrosia beetle (Platypus quercivorus ). Mycoscience 43:255-260

Linnakoski R, De Beer ZW, Ahtiainen J, Sidorov E, Niemelä P, Pappinen A, Wingfield MJ (2010) Ophiostoma spp. associated with pine and spruce-infesting bark beetles in Finland and Russia. Persoonia 25:72-93

Morrison AS, Lockhart SR, Bromley JG, Kim JY, Burd EM (2013) An environmental Sporothrix as a cause of corneal ulcer. Medical Mycology Case Reports 2:88-90

Mullineux T, Hausner G (2009) Evolution of rDNA ITS1 and ITS2 sequences and RNA secondary structures within members of the fungal genera Grosmannia and Leptographium. Fungal Genet Biol 46:855-867

Paine TD, Raffa KF, Harrington TC (1997) Interactions among scolytid bark beetles, their associated fungi, and live host conifers. Annu Rev Entomol 42:179-206

Pipe ND, Brasier CM, Buck KW (2000) Evolutionary relationships of the Dutch elm disease fungus Ophiostoma novo-ulmi to other Ophiostoma species investigated by restriction fragment length polymorphism analysis of the rDNA region. J Phytopathol 148:533-539

Ploetz RC, Hulcr J, Wingfield MJ, de Beer ZW (2013) Destructive Tree Diseases Associated with Ambrosia and Bark Beetles: Black Swan Events in Tree Pathology? Plant Dis 97:856872

Posada D (2008) Selection of models of DNA evolution with jModelTest. In: Posada D (ed), Bioinformatics for DNA sequence analysis, Humana Press, Totowa, pp. 93-112

Roets F, de Beer ZW, Dreyer LL, Crous PW, Zipfel R, Wingfield MJ (2006) Multigene phylogeny of Ophiostoma spp. associated with Protea infrutescenses including two new species. Studies in Mycology 55:199-212

Roets F, Dreyer LL, Crous PW, Wingfield MJ (2009) Mite-mediated hyperphoretic dispersal of Ophiostoma spp. from the infructescences of South African Protea spp. Environ Entomol 38:143-152 
Roets F, Wingfield MJ, Crous PW, Dreyer LL (2007) Discovery of fungus-mite mutualism in a unique niche. Environ Entomol 36:1226-1237

Romón P, De Beer ZW, Fernández M, Diez J, Wingfield BD, Wingfield MJ (2014a)

Ophiostomatoid fungi including two new fungal species associated with pine root-feeding beetles in northern Spain. Anton Leeuw 106:1167-1184

Romón P, De Beer ZW, Zhou X, Duong TA, Wingfield BD, Wingfield MJ (2014b)

Multigene phylogenies of Ophiostomataceae associated with Monterey pine bark beetles in Spain reveal three new fungal species. Mycologia 106:119-132

Ronquist FR, Teslenko M, Van der Mark P, Ayres DL, Darling A, Höhna S, Larget B, Liu L, Suchard MA, Huelsenbeck JP (2012) MrBayes 3.2: Efficient bayesian phylogenetic inference and model choice across a large model space. Syst Biol 61:539-542

Roux J, Malan R, Howitt M, Six DL, Wingfield MJ (2009) Fungi associated with diseased Euphorbia ingens in South Africa. 46th Biannual Conference of the Southern African Society for Plant Pathology, 25th-28 ${ }^{\text {th }}$ January 2009, Gordons Bay, South Africa

Schedl KE (1972) Monographie der Famile Platypodidae (Coleoptera). W. Junk, the Hague, p. 322

Scott DB, Du Toit JW (1970) Three new Raffaelea species. T Brit Mycol Soc 55:181-186

Six DL (2003) Bark beetle-fungus symbioses. In: Bourtzis K and Miller T (eds) Insect Symbioses, CRS press, USA, pp. 97-114

Six DL (2012) Ecological and evolutionary determinants of bark beetle - fungus symbioses. Insects 3:339-366

Six DL, Wingfield MJ (2011) The role of phytopathogenicity in bark beetle-fungus symbioses: A challenge to the classic paradigm. Annu Rev Entomol 56:255-272

Taerum SJ, Duong TA, De Beer ZW, Gillette N, Sun J-H, Owen DR, Wingfield MJ (2013) Large shift in symbiont assemblage in the invasive red turpentine beetle. PLoS ONE 8:e78126

Upadhyay HP (1981) A monograph of Ceratocystis and Ceratocystiopsis. University of Georgia Press, U.S.A.

Van Der Linde JA, Roux J, Wingfield, MJ, Six DL (2012) Die-off of giant Euphorbia trees in South Africa: Symptoms and relationships to climate. S Afr J Bot 83:172-185

VanWyk B, VanWyk P (1997) Field Guide to Trees of Southern Africa. Struik Publishers, South Africa

Vilgalys R, Hester M (1990) Rapid genetic identification and mapping of enzymatically amplified ribosomal DNA from several Cryptococcus species. J Bacteriol 172:4238-4246 
Webber JF (1990) The relative effectiveness of Scolytus scolytus, S. multistriatus and S. kirschii as vectors of Dutch elm disease. Eur J Forest Pathol 20:184-192

White TJ, Bruns T, Lee S, Taylor J (1990) Amplification and direct sequencing of fungal ribosomal RNA genes for phylogenetics. In: Innis MS, Gelfand DH, Sninsky JJ and White TJ (eds), PCR Protocols: A sequencing guide to methods and applications, Academic Press, San Diego, pp. 315-322

Wingfield MJ (1987) Fungi associated with the pine wood nematode, Bursaphelenchus xylophilus, and cerambycid beetles in Wisconsin. Mycologia 79:325-328

Wingfield MJ, Harrington TC, Solheim H (1995) Do conifer bark beetles require fungi to kill trees? In: Christiansen E (ed) Proceedings of bark beetles, blue-stain fungi, and conifer defense systems, Norwegian Forest Research Institute Symposium, Norway, p. 6

Whitney HS (1982) Relationships in bark beetles and symbiotic organisms. In: Mitton JB and Sturgeon KB (eds) Bark beetles in North America conifers, University of Texas, Austin, pp. $183-211$

Wood SL, Bright DE (1992) A catalog of Scolytidae and Platypodidae (Coleoptera), Part 2: Taxonomic index. Great Basin Nat Mem 13:1-1553

Zhou XD, De Beer ZW, Cibrian D, Wingfield BD, Wingfield MJ (2004) Characterisation of Ophiostoma species associated with pine bark beetles from Mexico, including $O$. pulvinisporum sp. nov. Mycol Res 108:690-698

Zhou XD, De Beer ZW, Wingfield BD, Wingfield MJ (2001) Ophiostomatoid fungi associated with three pine-infesting bark beetles in South Africa. Sydowia 53:290-300

Zhou XD, De Beer ZW, Wingfield MJ (2006) DNA sequence comparisons of Ophiostoma spp., including Ophiostoma aurorae sp. nov., associated with pine bark beetles in South Africa. Stud Mycol 55:269-277

Zipfel RD, De Beer ZW, Jacobs K, Wingfield BD, Wingfield MJ (2006) Multi-gene phylogenies define Ceratocystiopsis and Grosmannia distinct from Ophiostoma. Stud Mycol 55:75-97 


\section{Captions}

Fig. 1 Bayesian Inference consensus tree (LSU data) of taxa related to species isolated in the present study. Values above nodes indicate posterior probabilities $(>0.95)$ obtained through Bayesian Inference. Values below nodes indicate bootstrap values (1000 replicates, > 70) obtained from Maximum Likelihood analysis. Isolates in bold were collected in this study and/or present type species for the various genera. Other isolates (GenBank accession numbers and isolate numbers shown (when available)) were selected for comparative purposes. $\boldsymbol{b}=$ telemorph known

Fig. 2 Bayesian Inference consensus tree (ITS dat set I) of taxa related to species isolated in the present study. Values above nodes indicate posterior probabilities $(>0.95)$ obtained through Bayesian Inference. Values below nodes indicate bootstrap values (1000 replicates, > 70) obtained from Maximum Likelihood analysis. Isolates in bold were collected in this study and/or present type species for the various genera. Other isolates (GenBank accession numbers and isolate numbers shown (when available)) were selected for comparative purposes. $\boldsymbol{b}=$ telemorph known

Fig. 3 Bayesian Inference consensus tree ( $\beta$ t data) of members of the $S$. schenckii-O. stenoceras complex (De Beer et al. 2013). Values above nodes indicate posterior probabilities obtained through Bayesian Inference. Values below nodes indicate bootstrap values (1000 replicates) obtained from Maximum Likelihood analysis. Isolates in bold were collected in this study. Other isolates (GenBank accession numbers and isolate numbers shown (when available)) were selected for comparative purposes 
Fig. 4 a Beetle associate (Lanurgus sp. 1) of Raffaelea vaginata sp. nov. (scale bar $1 \mathrm{~mm}$ ). Micrographs of $R$. vaginata sp. nov.; b Perithecium removed from the gallery of Lanurgus sp. 1 in wood of Olea capensis ssp. macrocarpa (scale bar $100 \mu \mathrm{m}$ ); c Tip of perithecial neck (scale bar $10 \mu \mathrm{m}$ ); d Ascospores (scale bar $5 \mu \mathrm{m}$ ); e Two-week-old colony on MEA (scale bar $1 \mathrm{~cm}$ ); f-g Conidiophores with conidia (scale bars $5 \mu \mathrm{m}$ )

Fig. 5 a Beetle associate (Platypodinae sp. 1) of Raffaelea rapaneae sp. nov. (scale bar 1 $\mathrm{mm}$ ). Micrographs of $R$. rapaneae sp. nov.; b Two-week-old colony on MEA (scale bar 1 $\mathrm{cm}$ ); c-e Conidiophores with conidia (scale bars $5 \mu \mathrm{m}$ )

Fig. 6 a Beetle associate (Xyleborinus aemulus) of Sporothrix aemulophila sp. nov. (scale bar $1 \mathrm{~mm}$ ). Micrographs of $S$. aemulophila sp. nov.; b Perithecium removed from bark of Rapanea melanophloeos colonised by Xyleborinus aemulus (scale bar $100 \mu \mathrm{m}$ ); c Tip of perithecial neck showing ostiolar hyphae (scale bar $10 \mu \mathrm{m}$ ); d Ascospores (scale bar $10 \mu \mathrm{m}$ ); e Two-week-old colony on MEA (scale bar $1 \mathrm{~cm}$ ); f Conidiophore with conidiogenous cells showing denticles (scale bar $2 \mu \mathrm{m}$ ); g Conidia (scale bar $5 \mu \mathrm{m}$ ) 
$\stackrel{1}{83} \longrightarrow$ Cop. manitobensis DQ294358

S. lignivora complex

- Cop. minutabicolor DQ294359

L Cop. rollhanseniana DQ294362

LCop. neglecta CMW22403

Ceratocystiopsis

1 - Cop. minima DQ29436

- Cop. minuta EU913656

O. microsporum CMW17152

[ O. araucariae DQ294373

O. canum DQ294372

$\mathrm{H}$ o. piceae AF234837

O. karelicum EU443756

O.99 O. longiconidiatum CMW17574

O. pluriannulatum DQ294365

42 O. multiannulatum DQ294366

O. quercus DQ29437

o. floccosum AF234836

1 O. macrosporum AF282873

O. tingens AF282871

84 O. piliferum $\mathrm{DQ}$

- O. ips DQ294381

L O. pulvinisporum DQ294380

Ophiostoma s.l.

- O bragantinum CMW17149

O. fusiforme DQ294354

[ O. stenoceras DQ836904

S. variecibatus DQ821537

S. inflata DQ294351

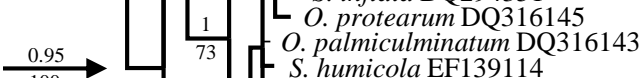

- S pallida EF139121

- O. phasma DQ31615

$0 . 9 7 \longdiv { \mathbf { C M W } }$ \%0363 deltoideosporum Hausner1993

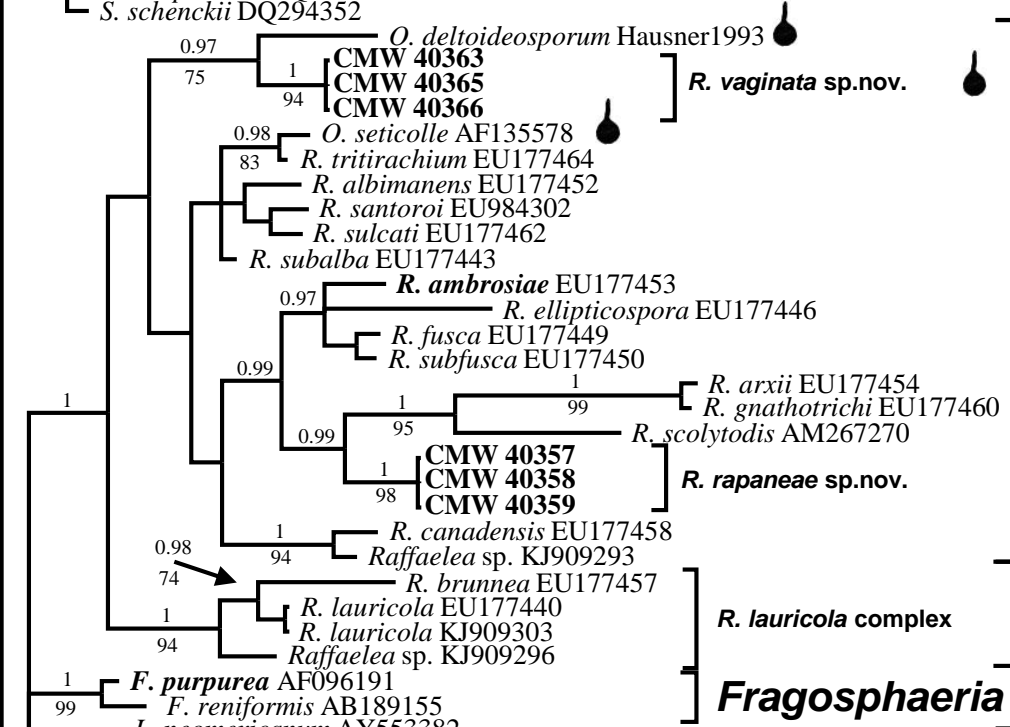

Raffaelea s.str.

L. neomexicanum AY553382

$[$ G. wageneri DQ294396

G. alacris JN135313

4 G. serpens JN135314

- L. pineti DQ062076

— G. abieticola GU134177

- L. procerum AY553386

- L. terebrantis EU296777

- L. truncatum DQ062052

- G. taigensis JF280017

- L. wingfieldii AY553398

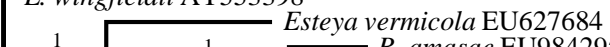

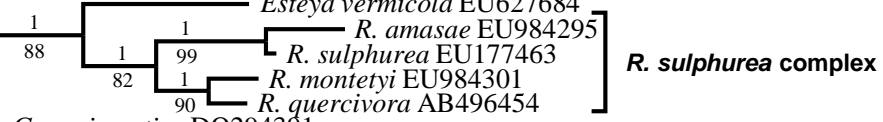

G. aenigmatica DQ29439 L $R$ sulphurea EU177463 . quercivora AB 49645

- $G$. laricis DQ294393

G. piceiperda DQ294392

- G. clavigera GENOME

- G. crassivaginata DQ294386 G. galeiformis DQ294383

G. leptographioides DQ294382

- G. grandifoliae DQ294399

G. huntii DQ294387

L. lundbergii DQ294388

F L. chlamydatum EU979333

T. curviconidium HQ406850

G. penicillata DQ294385

1 - L. abieticolens AF34370

90 L Listatum AY348304

Neurospora crassa AF286411 
Figure 2$] \quad$ Cop. minuta EU913696

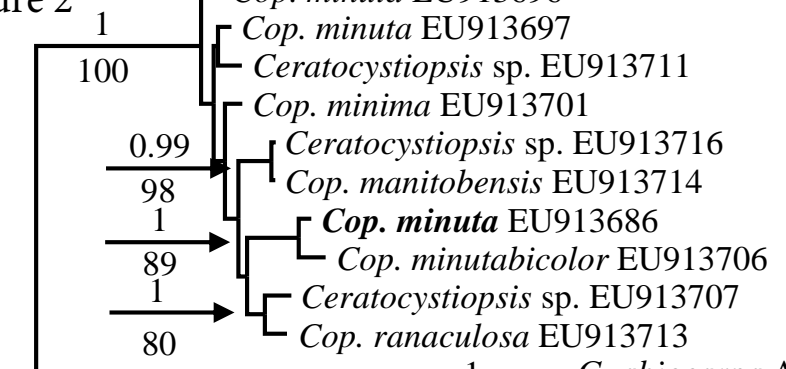

Ceratocystiopsis

Leptographium s.l.

R. sulphurea complex

$1 \stackrel{1}{100}$

78

G. laricis AJ538332

G. aurea AY935606

L. wingfieldii EU879155

f. Glavigera AY761158

L. terebrantis AY935609

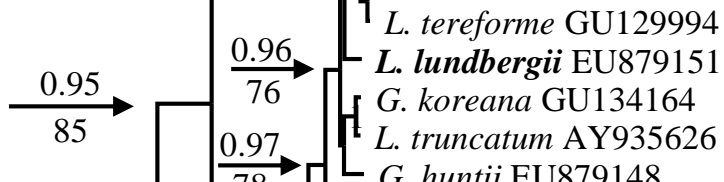

[ G. serpens EU879144

$0.94 \square\left[\begin{array}{l}\text { G. wageneri AY935596 } \\ \text { L. piriforme DQ885241 } \\ \text { L. procerum EU879143 }\end{array}\right.$

1 G. galeiformis AY649778

100 G. radiaticola EU879132

J G. cucullata AJ538335

1 G. davidsonii EU879127

$100\left[\begin{array}{l}\text { G. olivaceapini AJ538336 } \\ \text { G. olivacea AJ538337 }\end{array}\right.$

$1-{ }_{\text {R. quercusmongolicae } \mathrm{GQ} 22569}$

$1 \quad$ O. deltoideosporum EU879121

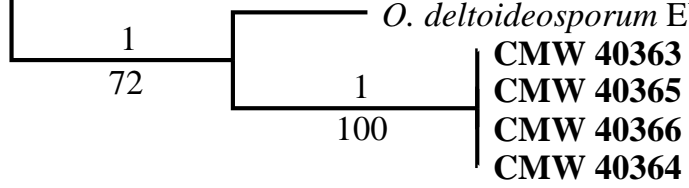

R. canadensis GQ225699

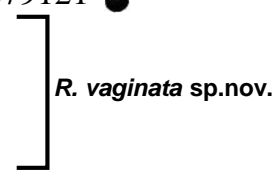

1

100

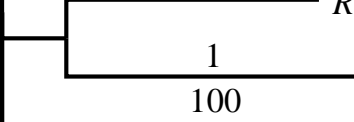

CMW 40357

CMW 40358

CMW 40359

R. lauricola KF515711

0.2

100
EU879136

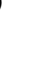

G. dryocoetidis AJ538340

R. scolytodis AM267270

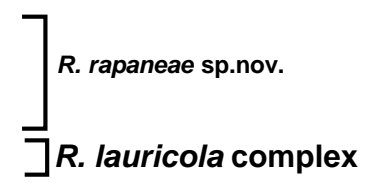

Raffaelea s.str. 


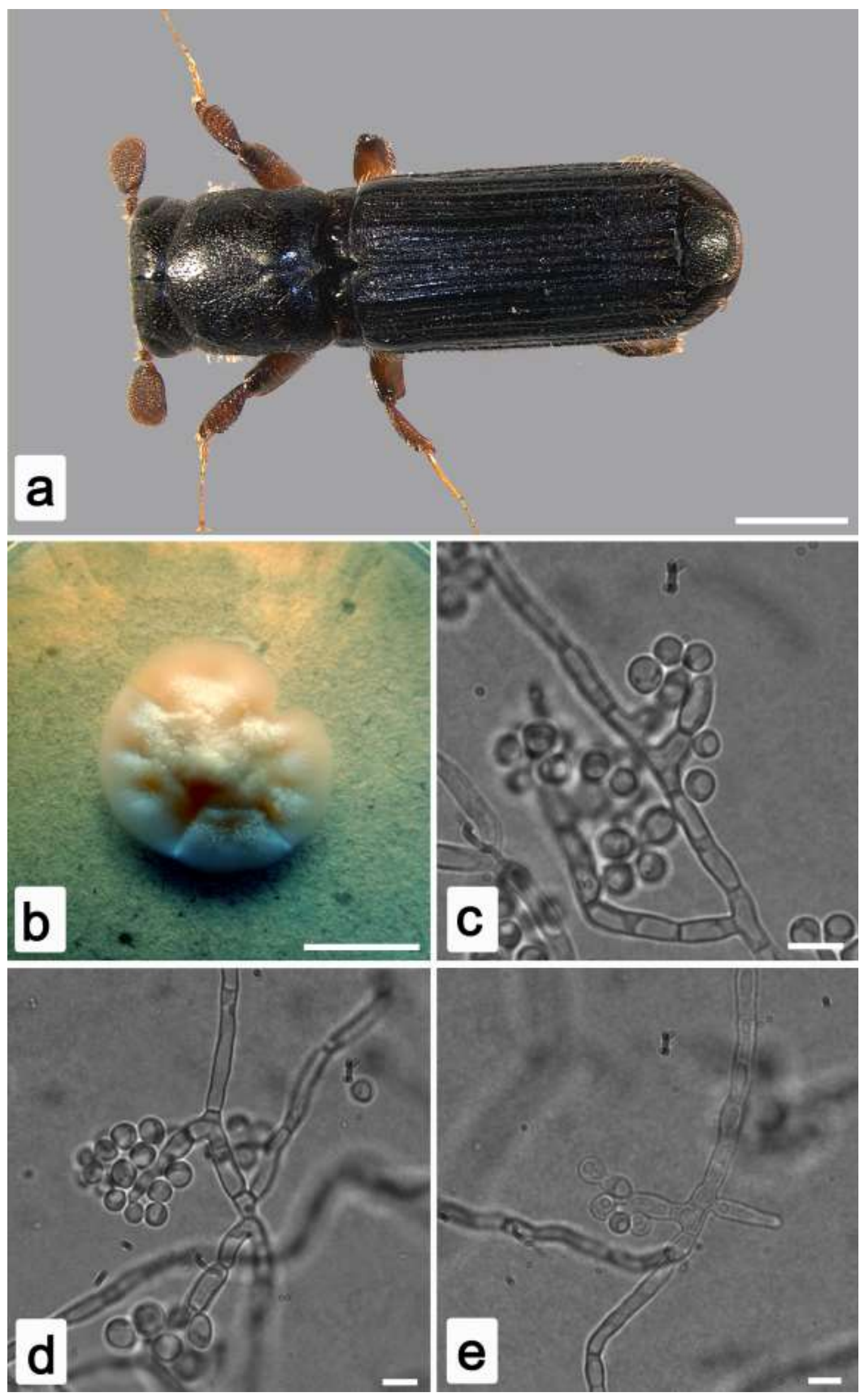




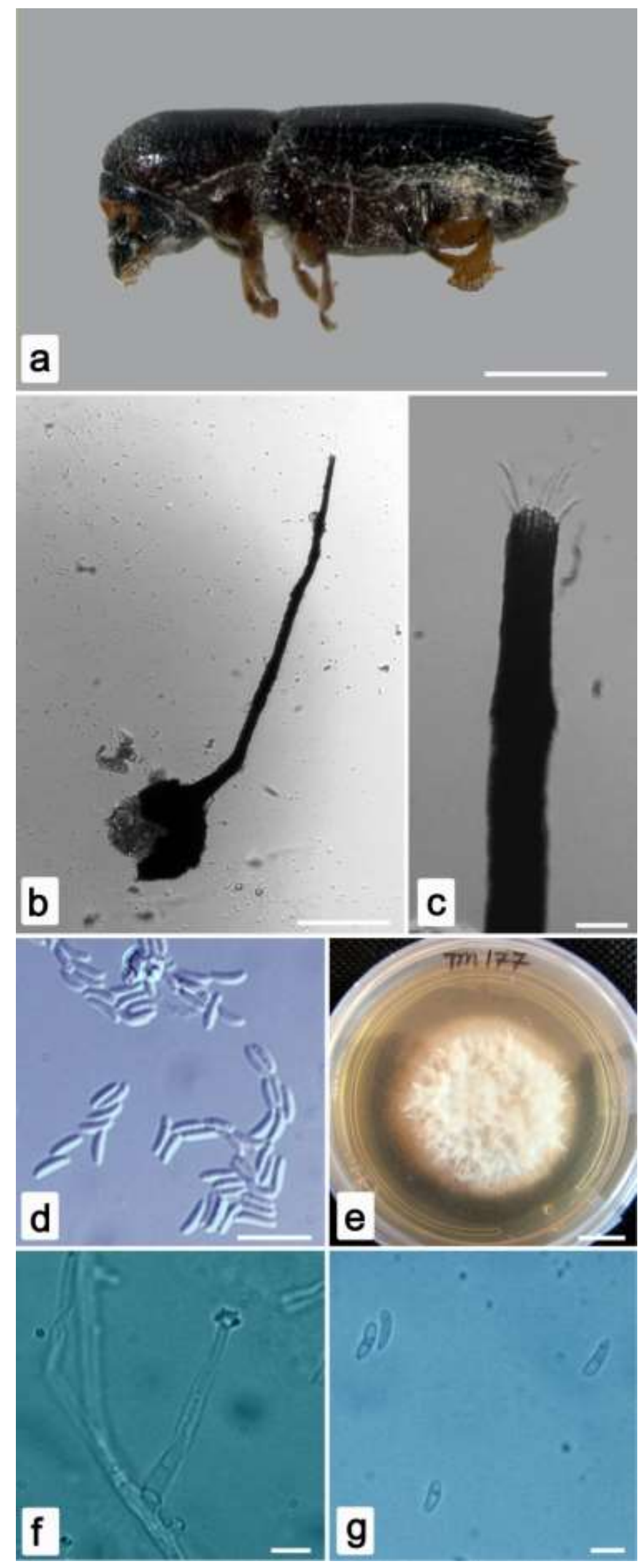


Table 1 Culture collection details and GenBank accession numbers for strains of ophiostomatoid fungi isolated from bark beetles in this study

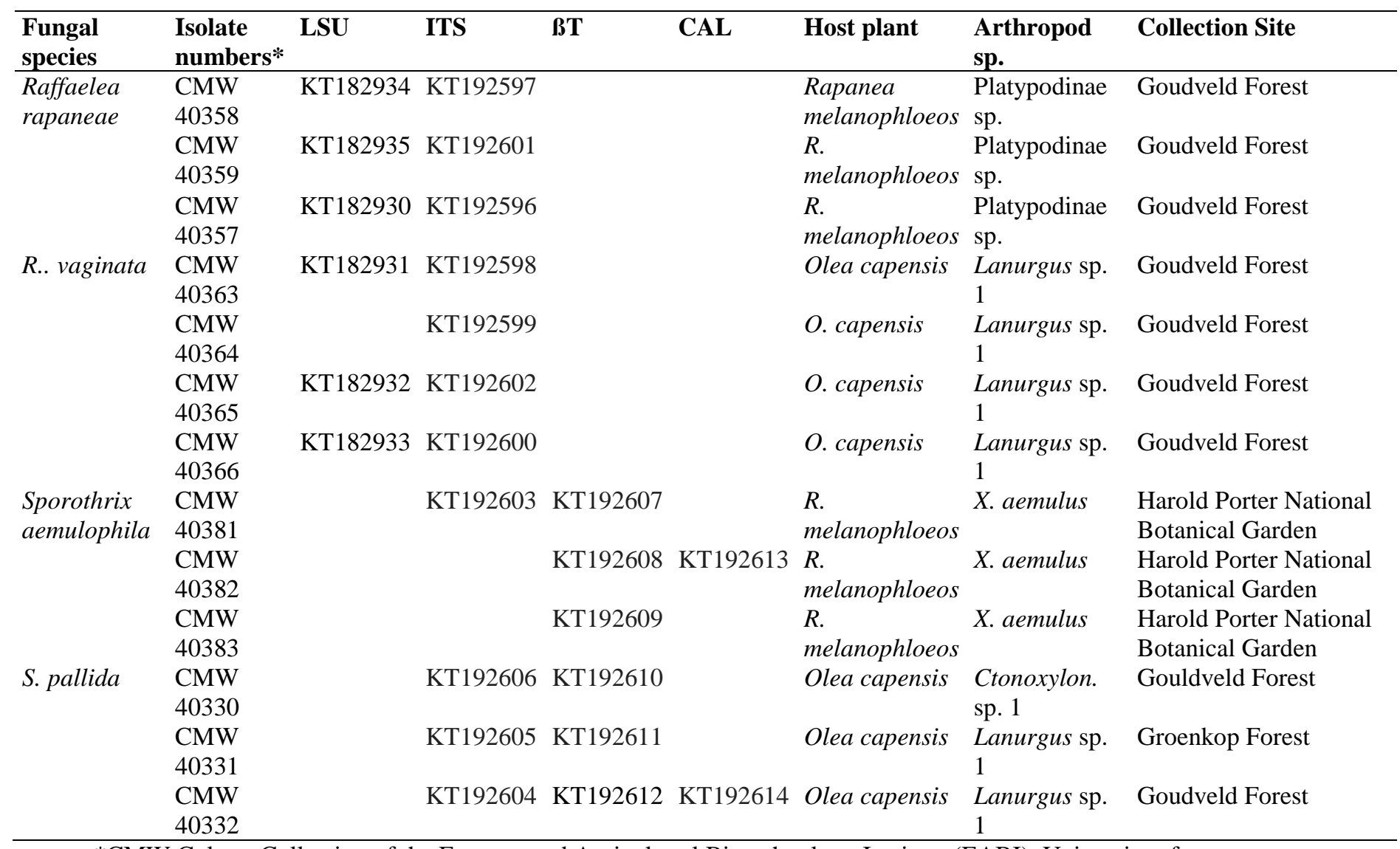

*CMW Culture Collection of the Forestry and Agricultural Biotechnology Institute (FABI), University of Pretoria, Pretoria, South Africa 
Supplementary resource 1 Parameters used and statistical values obtained from Maximum Likelihood (ML)

and Bayesian Inference (BI) analyses of the five datasets

\begin{tabular}{|c|c|c|c|c|c|c|}
\hline & Dataset & LSU & $\begin{array}{l}\text { ITS } \\
\text { (Data set I) }\end{array}$ & ITS (Data set II) & BT & CAL \\
\hline & Figure & Fig. 1 & Fig. 2 & Not shown & Fig. 3 & Fig. 4 \\
\hline \multirow[t]{6}{*}{ ML } & Substitution model & GTR+I+G & GTR+I+G & $\mathrm{GTR}+\mathrm{G}$ & $\mathrm{HKY}+\mathrm{G}$ & $\mathrm{GTR}+\mathrm{G}$ \\
\hline & Log-Likelihood & -5714.54 & -7474.46 & -9471.33 & -1611.87 & -3296.84 \\
\hline & Gamma shape & 0.772 & 1.037 & 0.421 & 0.161 & 0.483 \\
\hline & Invariant sites & 0.528 & 0.302 & - & - & - \\
\hline & $\begin{array}{l}\text { Relative rate } \\
\text { parameters }\end{array}$ & $\begin{array}{l}\text { A }<->\text { C } 0.65449 \\
\text { A }<->\text { G } 1.57440 \\
\text { A }<->\text { T } 0.83381 \\
\text { C r-> G } 0.57432 \\
\text { C r-> T } 7.90101\end{array}$ & $\begin{array}{l}\text { A }<->\text { C } 0.78758 \\
\text { A }<->\text { G } 2.66608 \\
\text { A }<->\text { T } 1.41052 \\
\text { C r-> G } 0.64323 \\
\text { C r-> T } 1.40778\end{array}$ & $\begin{array}{l}\text { A }<->\text { C } 1.34505 \\
\text { A r-> G } 1.86779 \\
\text { A }<->\text { T } 2.97916 \\
\text { C r-> G } 0.74761 \\
\text { C r-> T } 3.71590\end{array}$ & Kappa 2.678 & $\begin{array}{l}\text { A }<->C \text { C } 1.10508 \\
A<->\text { G } \\
4.15563 \\
\text { A r-> T } 1.08173 \\
\text { C r-> G } 0.51252 \\
\text { C r-> T } 2.88839\end{array}$ \\
\hline & Nucleotide frequencies & $\begin{array}{l}\mathrm{f}(\mathrm{A})=0.22535 \\
\mathrm{f}(\mathrm{C})=0.24605 \\
\mathrm{f}(\mathrm{G})=0.35098 \\
\mathrm{f}(\mathrm{T})=0.17762\end{array}$ & $\begin{array}{l}f(A)=0.15667 \\
f(C)=0.28696 \\
f(G)=0.39516 \\
f(T)=0.16120\end{array}$ & $\begin{array}{l}\mathrm{f}(\mathrm{A})=0.14568 \\
\mathrm{f}(\mathrm{C})=0.38779 \\
\mathrm{f}(\mathrm{G})=0.30294 \\
\mathrm{f}(\mathrm{T})=0.16359\end{array}$ & $\begin{array}{l}\mathrm{f}(\mathrm{A})=0.32456 \\
\mathrm{f}(\mathrm{C})=0.21748 \\
\mathrm{f}(\mathrm{G})=0.28703 \\
\mathrm{f}(\mathrm{T})=0.17093\end{array}$ & $\begin{array}{l}f(A)=0.23131 \\
f(C)=0.26439 \\
f(G)=0.28996 \\
f(T)=0.21433\end{array}$ \\
\hline \multirow[t]{8}{*}{ BI } & Likelihood & -6033.06 & -7577.97 & -5616.04 & -1751.89 & -3388.47 \\
\hline & $\begin{array}{l}\text { Average Effective } \\
\text { Sample Size of } \\
\text { Likelihood Value }\end{array}$ & 1679 & 3081 & 1282 & 1103 & 060 \\
\hline & $\begin{array}{l}\text { Most probable model } \\
\text { string }\end{array}$ & {$[121341]$} & {$[123133]$} & {$[122131]$} & [112212] & {$[121321]$} \\
\hline & $\begin{array}{l}\text { GTR Submodel } \\
\text { Probability }\end{array}$ & 0.22 & 0.08 & 0.23 & 0.07 & 0.19 \\
\hline & Gamma shape & 0.248 & 1.167 & 0.816 & 0.255 & 0.490 \\
\hline & Invariant sites & 0.385 & 0.291 & - & - & - \\
\hline & $\begin{array}{l}\text { Relative rate } \\
\text { parameters }\end{array}$ & $\begin{array}{l}\mathrm{r}(\mathrm{A}<->\mathrm{C}) 0.06073 \\
\mathrm{r}(\mathrm{A}<->\mathrm{G}) 0.14670 \\
\mathrm{r}(\mathrm{A}<->\mathrm{T}) 0.06534 \\
\mathrm{r}(\mathrm{C}<->\mathrm{G}) 0.05167 \\
\mathrm{r}(\mathrm{C}<->\mathrm{T}) 0.60765\end{array}$ & $\begin{array}{l}\mathrm{r}(\mathrm{A}<->\mathrm{C}) 0.11563 \\
\mathrm{r}(\mathrm{A}<->\mathrm{G}) 0.34641 \\
\mathrm{r}(\mathrm{A}<->\mathrm{T}) 0.14773 \\
\mathrm{r}(\mathrm{C}<->\mathrm{G}) 0.10079 \\
\mathrm{r}(\mathrm{C}<->\mathrm{T}) 0.15902\end{array}$ & $\begin{array}{l}A<->C \quad 0.09660 \\
A<->G \quad 0.15652 \\
A<->\text { T } 0.13106 \\
C<->\text { G } 0.09188 \\
C<->\text { T } 0.43588\end{array}$ & 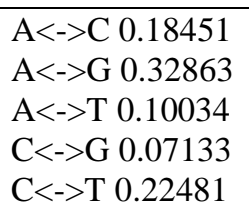 & $\begin{array}{l}A<->C 0.09411 \\
A<->G 0.36130 \\
A<->\text { T } 0.09359 \\
C<->\text { G } 0.06045 \\
C<->\text { T } 0.29894\end{array}$ \\
\hline & Nucleotide frequencies & $\begin{array}{l}\operatorname{pi}(A)=0.21102 \\
\operatorname{pi}(C)=0.25257 \\
\operatorname{pi}(G)=0.34097 \\
\operatorname{pi}(T)=0.19544\end{array}$ & $\begin{array}{l}\operatorname{pi}(A)=0.16118 \\
\operatorname{pi}(C)=0.28193 \\
\operatorname{pi}(G)=0.38282 \\
\operatorname{pi}(T)=0.17407\end{array}$ & $\begin{array}{l}\operatorname{pi}(A)=0.17783 \\
\operatorname{pi}(C)=0.36153 \\
\operatorname{pi}(G)=0.28041 \\
\operatorname{pi}(T)=0.18023\end{array}$ & $\begin{array}{l}\operatorname{pi}(A)=0.30968 \\
\operatorname{pi}(C)=0.21862 \\
\operatorname{pi}(G)=0.28593 \\
\operatorname{pi}(T)=0.18577\end{array}$ & $\begin{array}{l}\operatorname{pi}(\mathrm{A})=0.24015 \\
\operatorname{pi}(\mathrm{C})=0.25588 \\
\operatorname{pi}(\mathrm{G})=0.29127 \\
\operatorname{pi}(\mathrm{T})=0.21269\end{array}$ \\
\hline
\end{tabular}



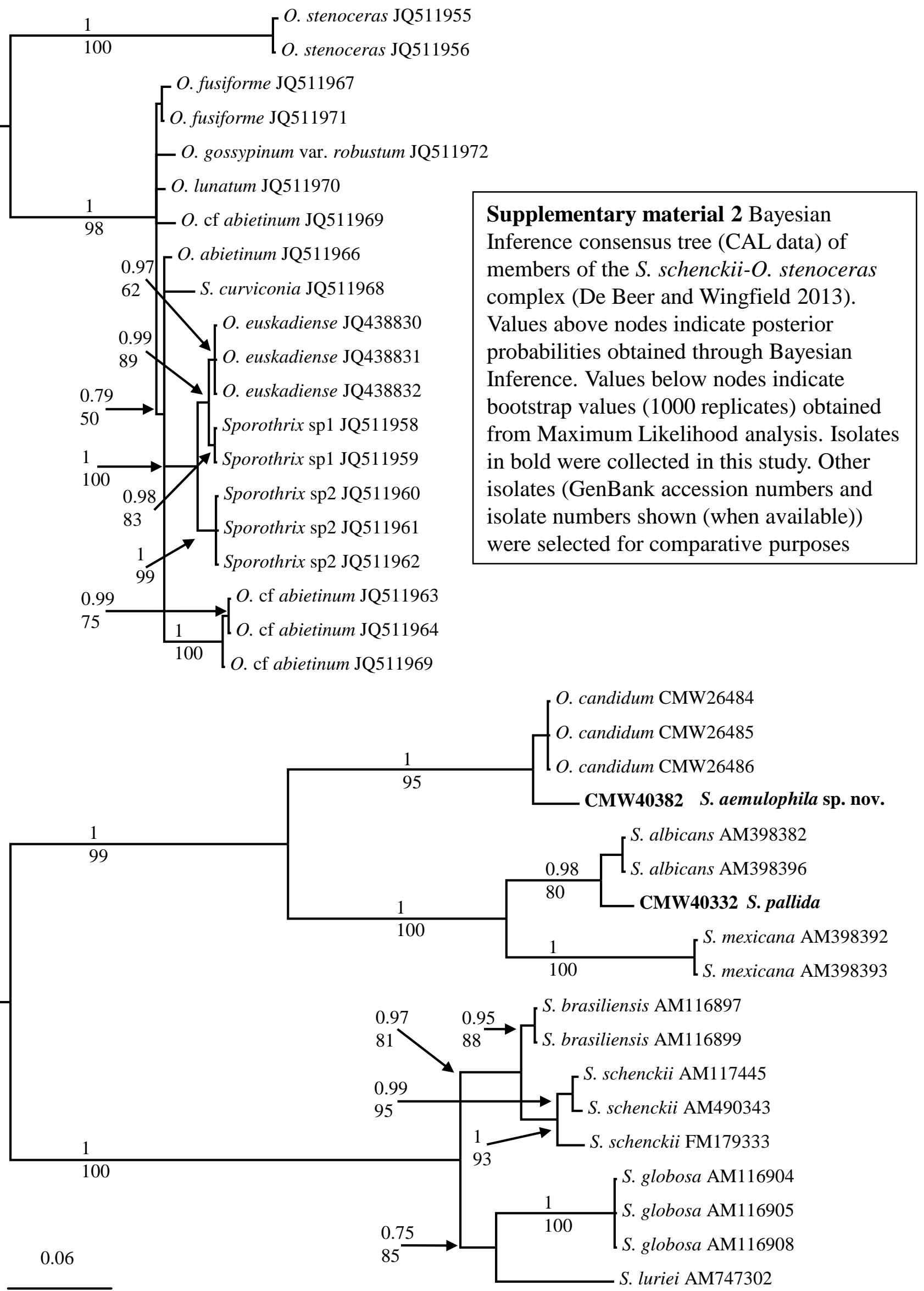